\title{
OPTIMALISASI KETERAMPILAN PEMBUATAN KEMASAN UNTUK MENINGKATKAN PEMASARAN PRODUK PADA UKM PEMBUAT TAPE DI DESA CIBEUREUM, KABUPATEN KUNINGAN
}

\author{
Dadang Suhardi \\ Program Studi Manajemen, Fakultas Ekonomi, Universitas Kuningan, Indonesia. \\ E-mail : dadang.suhardi@uniku.ac.id
}

\begin{abstract}
The government of Kuningan regency always tries to optimize natural resource in Kuningan regency which is expected to create self-competence and challenge as effort to stress Kuningan regency to be tourism city. One of the real implementation in supporting Kuningan regency as tourism city is by forming businesses. The specific business from Kuningan regency is 'tape ketan' (sweet cake made of slightly fermented and sticky rice). Tape ketan as one of the superior products exists as one of potential businesses owned by Kuningan regency. Mostly, the package of the products are still from plain mica pail.Besides, with the same package performance among tape producers, costumers judge that the taste of all tape product is the same. Formerly, the package functioned as place to protect and ease one product to carry but later on, the package is demanded to attract costumer to purchase. That's why the package used by the producers to pack 'tape' must be able to draw the costumers' attention to buy the tape products. In the activity of public service, the illumination of package role, material of the product, form of product, and package label have been given to the producers. Moreover,training of making interesting packaging product by the use of presentation, demonstration and practice methods have been implemented too. The social effects expected from this activity are that the tape producers realize the importance of interesting package for their products, make interesting package for their products, think more creative in designing package for their products, generate their sale, judge the costumer and loyal buyer easy to pick the product from the interesting package.
\end{abstract}

Keywords : packaging, label, Tape of Cibereum village

\begin{abstract}
Abstrak
Pemerintah Kabupaten Kuningan senantiasa berusaha untuk mengoptimalkan sumber daya alam yang ada di Kabupaten Kuningan yang diharapkan dapat menciptakan kemandirian dan daya saing sebagai upaya pemantapan Kabupaten Kuningan sebagai kota wisata.Salah satu bentuk nyata yang dilakukan oleh pemerintah dalam mendukung Kabupaten Kuningan sebagai kota wisata yaitu membentuk usaha-usaha. Adapun usaha yang menjadi ciri khas dari Kabupaten Kuningan adalah tape ketan.Tape ketan sebagai produk unggulan merupakan salah satu potensi yang dimiliki oleh Kabupaten Kuningan. Produk- produk yang dihasilkan sebagian besar juga masih menggunakan kemasan berupa ember dan mika polos. Selain itu, dengan seragamnya kemasan antar produsen tape terkadang membuat para pembeli berpendapat bahwa semua merek tape memiliki rasa yang sama. Pada awalnya sebuah kemasan berfungsi sebagai wadah yang digunakan untuk melindungi dan memudahkan suatu produk dibawa, tetapi seiring perkembangan zaman maka kemasan dituntut untuk menarik perhatian konsumen untuk membeli produk tersebut. Oleh karena itu, kemasan yang digunakan oleh produk tape harus mampu menarik juga calon konsumen untuk membeli produk tape.Pada kegiatan pengabdian masyarakat ini telah dilakukan penyuluhan mengenai peranan kemasan, bahan kemasan produk, bentuk kemasan produk, label kemasan, dan pelatihan pembuatan desain kemasan yang menarik dengan menggunakan metode presentasi, demonstrasi, dan praktek. Adapun dampak sosial yang diharapkan dalam kegiatan ini adalah produsen tape menyadari bahwa pentingnya kemasan yang menarik untuk produknya, produsen tape dapat membuat kemasan yang menarik untuk produknya, dapat berpikir lebih kreatif lagi dalam mendesain kemasan untuk produknya, produsen tape dapat meningkatkan penjualan produknya, dan calon konsumen dan pelanggan tetap dapat dengan mudah mengenali produk dari produsen tersebut dipandang dari kemasan yang menarik.
\end{abstract}

Kata Kunci : Kemasan, Label, Tape Desa Cibeureum 


\section{PENDAHULUAN}

Kabupaten Kuningan merupakan Kabupaten yang terletak di Jawa Barat. Kabupaten Kuningan merupakan jalur yang menghubungkan antara Bandung dengan Jawa Tengah melalui Kabupaten Majalengka. Pemandangan yang asri khas kaki Gunung Ciremai sepertinya telah memantapkan Kabupaten Kuningan sebagai kota wisata alam di daerah Jawa Barat yang diharapkan dapat berdampak pada peningkatan jumlah wisatawan domestik dan mancanegara. Pemerintah Kabupaten Kuningan seantiasa berusaha untuk mengoptimalkan sumber daya alam yang ada di Kabupaten Kuningan yang diharapkan dapat menciptakan kemandirian dan daya saing sebagai upaya pemantapan Kabupaten Kuningan sebagai kota wisata. Salah satu bentuk nyata yang dilakukan oleh pemerintah di Kabupaten Kuningan dalam rangka mendukung sebagai kota wisata adalah membentuk usaha-usaha (Suhendar dan Suhardi, 2018).

UKM merupakan bentuk usaha kecil menengah yang ada di kalangan masyarakat dimana pendiriannya didasarkan pada inisiatif seseorang. Salah satu peran penting dari UKM adalah mengurangi tingkat pengangguran yang ada. UKM diharapkan dapat menyerap tenaga kerja yang masih mengganggur. Selain itu, UKM juga telah berkontribusi besar pada peningkatan pendapatan daerah maupun negara Indonesia. UKM juga memanfaatkan berbagai sumber daya alam yang memiliki potensidi daerah 'yang belum diolah secara komersial. Oleh karena itu, jumlah dari UKM di Kabupaten Kuningan perlu ditingkatkan. Salah satu upaya yang dilakukan oleh pemerintah Kabupaten Kuningan untuk meningkatkan jumlah UMKM di Kabupaten Kuningan yaitu dengan mendukung berdirinya kelompok-kelompok usaha makanan. Salah satu makanan yang menjadi ciri khas Kabupaten Kuninganini adalah tape ketan.

Tape adalah salah satu makanan selingan yang cukup populer di Wilayah Indonesia dan Malaysia. Pada dasarnya, terdapat dua jenis dari tape iniyaitu tape ketan dan tape singkong. Tape ini baik tape ketan maupun tape singkong ini memiliki rasa manis dan tape ini juga sedikit mengandung alkohol, serta tape ini memiliki tekstur yang lunak dan berair. Kondisi tape ini cepat rusak karena tape ini melalui proses fermentasi lanjutan setelah kondisi fermentasi yang maksimal tercapai sehingga tape harus segera dikonsumsi. Tape ini dapat bertahan lebih dari satu minggu apabila tape ini melalui proses pengolahan yang baik. Tape ketan sebagai produk unggulan merupakan salah satu potensi yang dimiliki oleh Kabupaten Kuningan. Usaha tape ketan kini semakin meningkat dan menjadi usaha yang menyediakan lapangan kerja sekaligus peluang usaha. Usaha produksi tape ketan di Kabupaten Kuningan tersebar di tiga kecamatan yaitu Kecamatan Cibeureum, Kecamatan Sindangagung dan Kecamatan Cigugur.Produk- produk yang dihasilkan sebagian besar juga masih menggunakan kemasan berupa ember dan mika polos. Identitas produsen seringkali dibuat dalam bentuk stiker yang dilampirkan di depan kemasan mika dan ember. Selain itu, dengan seragamnya kemasan antar produsen tape terkadang membuat para pembeli berpendapat bahwa semua merek tape memiliki rasa yang sama. Padahal produk yang dihasilkan seringkali juga digunakan sebagai oleh-oleh yang dibeli oleh pendatang dari luar kota. 
Kemasan merupakan wadah yang berfungsi untuk melindungi sebuah barang agar aman, menarik perhatian orang yang melihatnya, sertakemasan juga berfungsi sebagai daya tarik untuk memikat konsumen atau seseorang yag ingin membeli suatu produk. Kemasan adalah salah satu kunci dalam menjaga kualitas produk. Kottler dan Amstrong (2012) mengemukakan bahwa kemasan mencakup kegiatan mendesain dan memproduksi yang bertujuan untuk melindungi produk. Kemasan juga dapat dijadikan sebagai sebuah media komunikasi antara para produsen dengan calon konsumennya sehingga kemasan yang baik adalah kemasan yang mencantumkan informasi-informasi mengenai hal-hal apa saja yang diketahui oleh calon pembeli sehingga pembeli dapat dengan mudah mengenali porduk yang dia beli melalui kemasannya. Selain untuk melindungi produk, kemasan juga berfungsi sebagai media pemasaran yang handal. Adanya kemasan yang baik hendaknya dapat menjadi media komunikasi atau promosi yang dapat mendongkrak penjualan karena kemasanpada saat ini mengalami pergeseran atau perubahan fungsi yang awalnya kemasan hanya berfungsi untuk melindungi sebuah produk, sekarang kemasan berfungsi sebagai alat untuk mengidentifikasi sebuah merek dagang dari suatu produk. Pada akhirnya, dengan adanya perkembangan kemasan menjadikan kemasan sebagai bagian dari ujung tombak promosi suatu produk sehingga kemasan berfungsi meningkatkan nilai jual dari sebuah produk.Berdasarkan uraian di atas, maka produsen tape dapat mengemas produk mereka dengan menarik dengan tetap menjaga kualitas produk. Oleh karena itu, penulis tertarik untuk melakukan pengabdian pada masyarakat pada salah satu UKM pembuat tape di Desa Cibeureum. Kecamatan Cibeureum, Kabupaten Kuningandengan tema "Optimalisasi Keterampilan Pembuatan Kemasan untuk Meningkatkan Pemasaran Produk Tape”. Sasaran dan lokasi kegiatan. sasaran dalam Pengabdian Kepada Masyarakat ini adalah Usaha Kecil Menengah (UKM) Tape dan masyarakat secara keseluruhan yang berdomisili di Desa Cibeureum. Kecamatan Cibeureum, Kabupaten Kuningan.

\section{METODE PELAKSANAAN}

Kegiatan pengabdian pada masyarakat ini ditujukan untuk memberikan pengetahuan dan keterampilan pembuatan kemasan produk tape bagi produsen tape di Desa Cibeureum. Kecamatan Cibeureum, Kabupaten Kuningan. Adapun metode yang digunakan dalam kegiatan ini adalah presentasi, demonstrasi, dan praktik secara individu maupun kelompok.

1. Metode presentasi yaitu Metode ini digunakan untuk menyampaikan beberapa hal yang berkaitan dengan manfaat, fungsi, bahan alat, bagaimana cara membuat kemasan produk, mulai dari awal sampai akhir.

2. Metode Demonstrasi, yaitu Metode ini digunakan untuk mempertunjukkan cara pembuatan kemasan produk tape. Diharapkan dengan adanya metode ini para peserta dapat mempraktikkan langsung membuat kemasan dan label produk.

3. Metode Praktik, yaitu Metode ini dilakukan untuk melatih para produsen tape di Desa Cibeureum. Kecamatan Cibeureum, Kabupaten Kuningan dalam membuat 
kemasan. Metode ini dilakukan agar para produsen tape tersebut mempunyai pengalaman langsung tentang pembuatan kemasan dan label produknya.

\section{HASIL DAN PEMBAHASAN}

\section{Profil Desa Cibeureum Kecamatan Cibeureum Kabupaten Kuningan}

Wilayah adminsitrasi dari Desa Cibeureum dibagi menjadi tujuh buah kampung atau blok yaitu :

1. Blok Senen;

2. Blok Kemis;

3. Blok Saptu;

4. Cibeureum sendiri dibagi empat wilayah yaitu
a. Blok Salasa;
b. Blok Rebo;
c. Blok Jumat;
d. Blok Ahad.

Seiring berjalannya waktu, penduduk di daerah tersebut semakin padat sehingga aparatur pemerintah di Desa Cibeureum memperkirakan tidak akan bisa mengayomi masyarakatnya secara keseluruhan sehingga pada tahun 1982 dibawah kepemimpinan kepala desa E. Suyatno dan dengan ijin dari Pemerintah Kabupaten Kuningan maka Desa Cibeureum dibagi menjadi 4 Desa otonomi yaitu:

1. Desa Cibeureum yang membawahi 4 dusun atau blok yaitu Blok Rebo, Blok salasa, Blok Jamahat dan Blok Ahad

2. Desa Tarikolot

3. Dusun Cirarang yang berubah nama menjadi Desa Sukadana

4. Dusun Cibangkawang yang berubah nama menjadi Desa Randusari

Maka sejak tahun 1982 Desa Cibeureum membawahi 4 buah dusun yaitu :

1. Yang semula Blok Jamahat dirubah namanya menjadi Dusun I

2. Yang semula Blok Ahad dirubah namanya menjadi Dusun II

3. Yang semula Blok Rebo dirubah namanya menjadi Dusun III

4. Yang semula Blok salasa dirubah namanya menjadi Dusun IV

Batas Wilayah Administrasi

\begin{tabular}{|c|l|l|}
\hline No & Batas Wilayah & \multicolumn{1}{|c|}{ Desa / Kecamatan } \\
\hline 1. & Sebelah Utara & Tarikolot \& Sukadana / Cibeureum \\
\hline 2. & SebelahTimur & Sukamaju / Cibingbin \\
\hline 3. & Sebelah Selatan & Sumurwiru / Cibeureum \\
\hline 4. & Sebelah Barat & Randusari / Cibeureum \\
\hline
\end{tabular}


Luas wilayah menurut penggunaan

\begin{tabular}{|c|l|c|}
\hline No & \multicolumn{1}{|c|}{ Uraian } & Jumlah ( ha ) \\
\hline 1. & Luas wilayah & 819.646 \\
\hline 2. & Tanah sawah & 243 \\
\hline 3. & Tanah Pekarangan & 39.5 \\
\hline 4. & Tanah Tegalan / Ladang & 107 \\
\hline 5. & Lain-lain & 49.74 \\
\hline
\end{tabular}

\section{KeadaanTopografi Desa}

Secara umum Desa Cibeureum merupakan daerah Dataran rendah dan perbukitan dengan ketinggian sekitar $175 \mathrm{~m}$ diatas permukaan laut.

\section{Visi dan Misi Desa Cibeureum}

Visi adalah sebuah gambaran yang menantang tentang keadaan masa depan yang diinginkan dengan melihat potensi dan kebutuhan desa. Penyusunan Visi Desa Cibeureum dilakukan dengan pendekatan partisifatif, melibatkan pihak-pihak berkepentingan di Desa Cibeureum seperti Pemerintah Desa, BPD, tokoh masyarakat, Tokoh Agama, Lembaga Masyarakat Desa pada umumnya. Pertimbangan kondisi internal dan eksternal, mengafresiasikan kekuatan dan kelemahan yang ada dan berusaha untuk memahami berbagai peluang dan tantangan yang dihadapi sehingga upaya untuk mencapai suatu cita-cita bersama perlu ditetapkannya Visi Pemerintahan Desa Cibeureum yang merupakan Satuan Wilayah Kerja pembangunan di Kecamatan Cibeureum, mempunyai titik berat di sektor infrastruktur. Maka berdasarkan Pertimbangan di atas Visi Desa Cibeureum adalah:

Visi Desa Cibeureum Kecamatan Cibeureum yaitu :

\begin{tabular}{|c|c|}
\hline \multicolumn{2}{|r|}{ “ $\underline{S A N T U N}$ “ } \\
\hline$S$ & $\begin{array}{l}\text { Sepakat dalam menentukan dan memutuskan setiap kebijakan pembangunan desa, } \\
\text { serius dalam menghadapai setiap bidang pembangunan, dan sukses dalam setiap } \\
\text { pelaksanaan program pembangunan desa }\end{array}$ \\
\hline $\mathbf{A}$ & $\begin{array}{l}\text { Amanah dalam mengemban dan melaksanakan tugas dan kewajiban selaku } \\
\text { perangkat desa Cibeureum }\end{array}$ \\
\hline $\mathbf{N}$ & $\begin{array}{l}\text { Netral dalam menyikapi berbagai permasalahan sosial yang muncul di desa } \\
\text { Cibeureum }\end{array}$ \\
\hline $\mathbf{T}$ & $\begin{array}{l}\text { Taqwa, Tabah, Tawadlu terpadu dalam menyikapi dan melaksanaan tugas dn } \\
\text { tanggungjawab untuk mendapat magfiroh Allah SWT }\end{array}$ \\
\hline $\mathbf{U}$ & $\begin{array}{l}\text { Untuk bersama kita bahu membahu demi terwujudnya cita-cita kesejahteraan } \\
\text { masyarakat yang madani dan hakiki }\end{array}$ \\
\hline $\mathbf{N}$ & $\begin{array}{l}\text { Nyata dalam memperjuangkan dan mewujudkan cita-cita bersama demi desa } \\
\text { tercinta }\end{array}$ \\
\hline
\end{tabular}


Misi Desa Cibeureum Kecamatan Cibeureum :

Dalam rangka pencapaian Visi Desa Cibeureum Kecamatan Cibeureum maka dirumuskan Misi sebagai berikut :"BERSAMA “ membangun desa menuju Desa Cibeureum maju, bermartabat dan berwibawa yang ditopang kesejahteraan masyarakat yang cerdas dan harmonis secara adil, agamis dalam kerangka 4 pilar kebangsaan.

\section{Tahapan Kegiatan}

Tahapan kegiatan program PkM adalah sebagai berikut:

a. Tahap persiapan

1) Pra-Survei.

2) Pembentukan Tim PkM.

3) Pembuatan Proposal.

4) Koordiasi Tim dan Mitra.

5) Persiapan Alat dan Bahan Pelatihan.

b. Tahap pelaksanaan (Kegiatan dilaksanakan di lokasi mitra)

1) Sosialisasi Pentingnya Kemasan untuk UKM.

2) Sosialisasi materi UKM.

3) Praktek dan simulasi.

c. Pelaporan

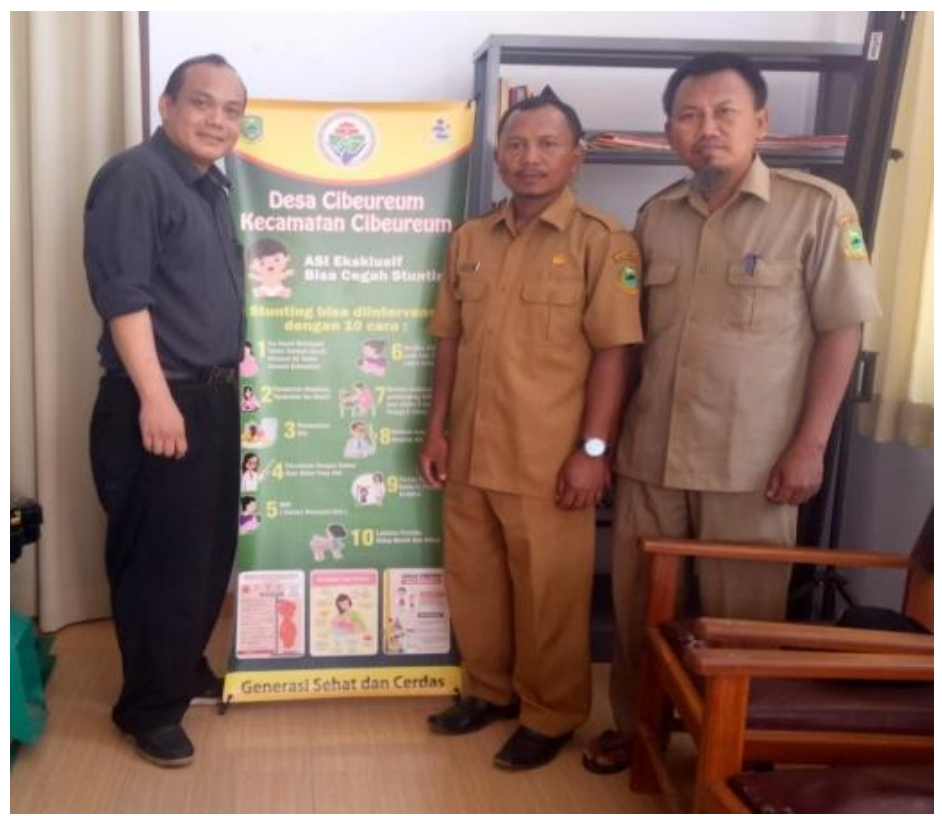

Gambar 1.

Penyambutan pemateri oleh perangkat Desa

Desa Cibereum Kecamatan Cibeureum 


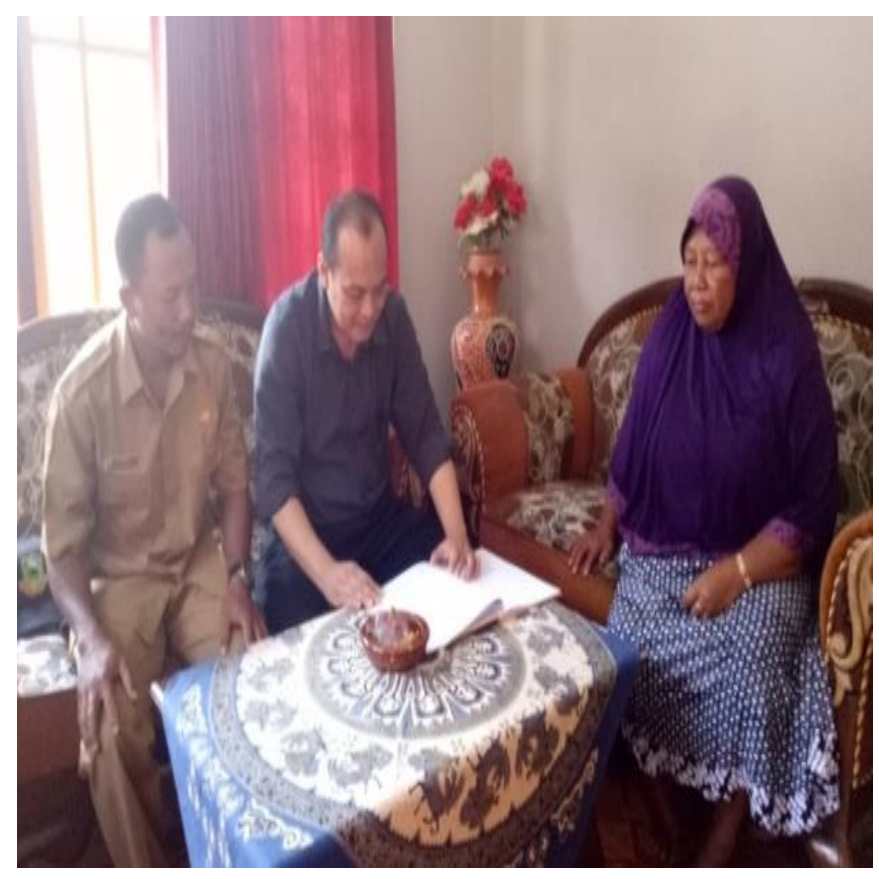

Gambar 2.

Pra-Survei : Identifikasi permasalahan dan

kebutuhan mitra (permasalahan spesifik yang dialami mitra).

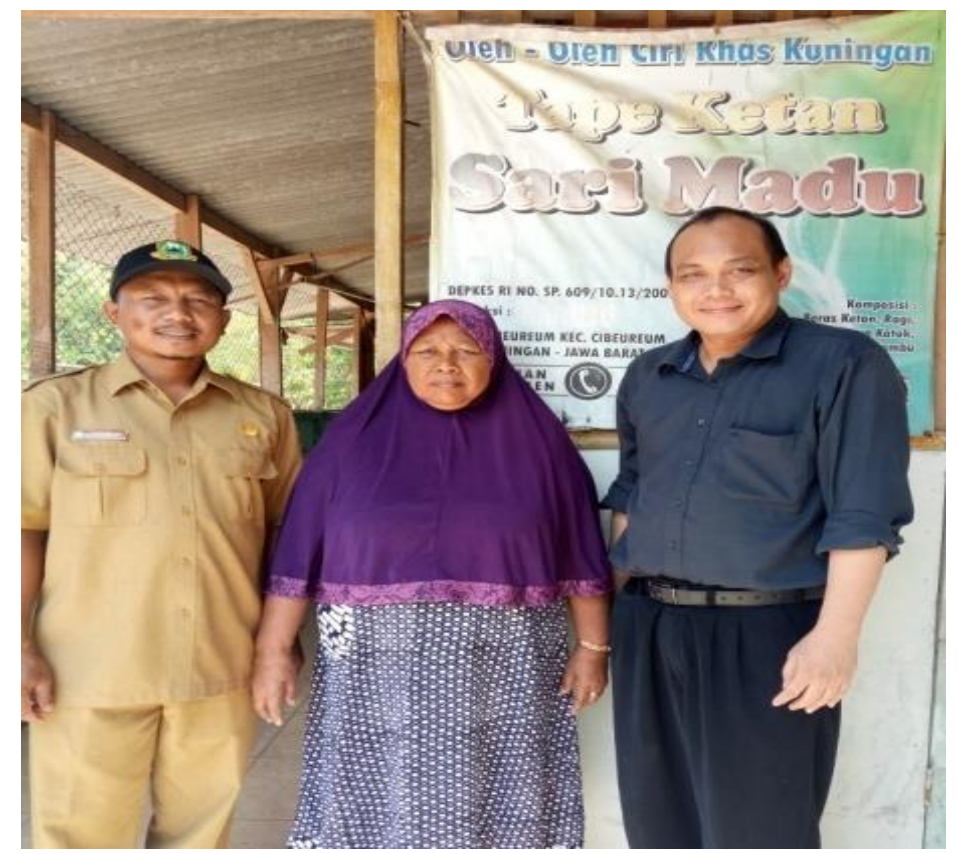

Gambar 3.

Kunjungan ke lokasi pembuatan Tape

Di Desa Cibereum Kecamatan Cibeureum 
Tabel 1. Jadwal Kegiatan

\begin{tabular}{|c|c|c|}
\hline WAKTU & ACARA & PENANGGUNGJAWAB \\
\hline \multicolumn{3}{|c|}{ Sabtu, 24 Agustus 2019} \\
\hline $15.00-15.30$ & Persiapan & Tim PkM dan mitra \\
\hline $15.30-15.45$ & Pembukaan acara & $\begin{array}{l}\text { PerwakilanTim PkM } \\
\text { Perwakilan Desa }\end{array}$ \\
\hline $15.45-16.45$ & $\begin{array}{l}\text { Materi mengenai Kemasan } \\
\text { (Diskusi/tanya jawab) }\end{array}$ & Dadang Suhardi, SE,MM \\
\hline $16.45-17.00$ & Penutupan acara & $\begin{array}{l}\text { PerwakilanTim PkM } \\
\text { Perwakilan Desa }\end{array}$ \\
\hline \multicolumn{3}{|c|}{ Minggu, 25 Agustus 2019} \\
\hline $15.00-15.30$ & Persiapan & Tim PkM dan mitra \\
\hline $15.30-15.45$ & Pembukaan acara & $\begin{array}{l}\text { PerwakilanTim PkM } \\
\text { Perwakilan Desa }\end{array}$ \\
\hline $15.45-16.45$ & $\begin{array}{l}\text { Materi mengenai Desain Kemasan } \\
\text { (Diskusi/tanya jawab) }\end{array}$ & Dadang Suhardi, SE,MM \\
\hline $16.45-17.00$ & Penutupan acara & $\begin{array}{l}\text { PerwakilanTimPkM } \\
\text { Perwakilan Desa }\end{array}$ \\
\hline \multicolumn{3}{|c|}{ Senin, 26 Agustus 2019} \\
\hline $15.00-15.30$ & Persiapan & Tim PkM dan mitra \\
\hline $15.30-15.45$ & Pembukaan acara & $\begin{array}{l}\text { PerwakilanTim PkM } \\
\text { Perwakilan Desa }\end{array}$ \\
\hline $15.45-16.45$ & $\begin{array}{l}\text { Jenis-jenis bahan kemasan } \\
\text { (Diskusi/tanya jawab) }\end{array}$ & Dadang Suhardi, SE,MM \\
\hline $16.45-17.00$ & Penutupan acara & $\begin{array}{l}\text { PerwakilanTim PkM } \\
\text { Perwakilan Desa }\end{array}$ \\
\hline
\end{tabular}

\section{Pengertian Kemasan}

Kotler dan Amstrong (2012) mendefinisikan bahwa proses kemasan melibatkan kegiatan mendesain dan memproduksi sebuahw adah yang memiliki fungsi utama yaitu untuk melindungi produk agar kualitas dari produk tetap terjaga. Nillson \& Ostrom (2005) mengemukakan bahwa terdapat 3 dimensi dalam variabel desain kemasan yaitu sebagai berikut :

1. Desain grafis : desain visual yang ada pada permukaan kemasan dimana desain grafis ini terdiri dari empat indikator meliputi nama merek, warna dari kemasan, tipografi, dan gambar.

2. Struktur desain berhubungan dengan fitur-fitur fisik kemasan dan struktur desain terdiri dari 3 sub-dimensi yaitu bentuk, ukuran, dan material.

3. Informasi produk : informasi produk biasanya tertera di dalam kemasan dapat berupa nama merek, tanggal produksi dan tanggal kadaluarsa, nilai gizi per kemasan, informasi perusahaannya, dan lain sebagainya. 


\section{Tujuan dan Fungsi Kemasan}

Fungsi dari kemasan adalah untuk mewadahi dan melindungi produk dari kerusakan yang tidak diinginkan. Simamora (2007) mengemukakan bahwa terdapat beberapa fungsi dari kemasan yaitu sebagai berikut:

1. Fungsi protektif : menghindari berbagai kemungkinan kerusakan produk bisa karena iklim, prasarana transportasi, distribusi, dan lain sebagainya sehingga dengan fungsi ini diharapkan konsumen tidak perlu menanggung resiko barang yang rusak.

2. Fungsi promosional : kemasan yang memiliki kualitas yang baik secara warna, ukuran, dan penampilan akan memiliki daya tarik untuk menarik perhatian pembeli sehingga pembeli itu membeli produk tersebut.

Selain kedua fungsi di atas, adapun fungsi lainnya dari kemasan yaitu memudahkan distribusi produk, produk tidak tercecer, identitas produk yang membedakan produk itu dengan produk lainnya, serta dapat menambah daya tarik calon pembeli.

\section{Jenis-Jenis Bahan Kemasan}

Pemilihan bahan yang digunakan dalam suatu kemasan harus disesuaikan dengan jenis produk yang akan kita hasilkan, apakah produk itu termasuk olahan basah, kering, atau yang lainnya. Suatu kemasan yang baik akan berdampak pada peningkatan estetika produk sehingga diharapkan konsumen akan tertarik untuk membeli produk itu. Selain itu, kemasan juga dapat menjaga kualitas sebuah produk dari udara luar yang dapat menyebabkan produk cepat basi, kotor, dan lainnya. Berbagai jenis kemasan makanan tradisional yang sering dijumpai seperti kemasan yang menggunakan daun pisang, kelobot jagung, daun kelapa/enau (aren), daun jambu air atau daun jati, sedangkan jenis bahan kemasan secara modern dapat berupa: kertas, alumunium foil, film, plastik.

Julianti dan Nurminah (2006) mengemukakan bahwa kemasan dapat diklasifikasikan berdasarkan beberapa hal yaitu sebagai berikut :

1. Klasifikasi kemasan yang didasarkan pada frekuensi pemakaian:

a. Kemasan sekali pakai (disposable) : kemasan yang langsung dibuang setelah dipakai.

b. Kemasan yang dapat dipakai berulangkali (multitrip)

c. Kemasan yang tidak dibuang atau dikembalikan oleh konsumen (semi disposable)

2. Klasifikasi kemasan berdasarkan struktur sistem kemas (kontak produk dengan kemasan) :

a. Kemasan primer : langsung bersentuhan dengan produk-produk yang dibungkusnya. 
b. Kemasan sekunder : tidak bersentuhan langsung dengan produk-produknya tetapi membungkus produk yang telah dikemas dengan menggunakan kemasan primer.

c. Kemasar tersier dan kuartener yaitu kemasan untuk mengemas produkproduk setelah kemasan primer atau sekunder.

3. Klasifikasi kemasan berdasarkan sifat kekakuan bahan kemasan :

a. Kemasan fleksibel : bahan kemasan yang mudah dilenturkan tanpa adanya retak atau patah.

b. Kemasan kaku yaitu bahan kemas yang bersifat keras, kaku, dan tidak tahan lenturan,

c. Kemasan semi kaku/semi fleksibel yaitu bahan kemas yang memiliki sifat-sifat antara kemasan fleksibel dan kemasan kaku.

4. Klasifikasi kemasan berdasarkan sifat perlindungan terhadap lingkungan:

a. Kemasan hermetis (tahan uap dan gas) : kemasan yang secara sempurna tidak dapat dilalui oleh gas, udara atau uap air sehingga selama masih hermetis wadah ini tidak dapat dilalui oleh bakteri, kapang, ragi dan debu. Misalnya kaleng, botol gelas yang ditutup secara hermetic.

b. Kemasan tahancahaya yaitu wadah yang tidak bersifat transparan, misalnya kemasan logam, kertas dan foil. Kemasan ini cocok untuk bahan pangan yang mengandung lemak dan vitamin yang tinggi, serta makanan hasil fermentasi.

c. Kemasan tahan suhu tinggi, yaitu kemasan untuk bahan yang memerlukan proses pemanasan, pasteurisasi dan sterilisasi. Umumnya terbuat dari logam dan gelas.

5. Klasifikasi kemasan berdasarkan tingkat kesiapan pakai (perakitan):

a. Kemasan siap pakai: siap untuk diisi dengan bentuk yang telah sempurna. Contoh : botol, wadah kaleng dan sebagainya.

b. Kemasan siap dirakit atau kemasan lipatan : kemasan yang masih memerlukan tahap perakitan sebelum diisi.

\section{Desain Kemasan}

Pada awalnya, fungsi kemasan adalah sebgai perlindungan dan pemudahan dari suatu produk untuk dibawa tetapi dengan adanya perkembangan zaman maka adanya peralihan fungsi dari kemasan. Kemasan dituntut untuk mampu menumbuhkan daya tarik seorang konsumen untuk membeli produk tersebut sehingga dalam proses perancaangan kemasan maka seorang produsen tidak boleh sembarangan dalam merancangnya. Produsen dituntut memiliki ide-ide yang yang mampu mendesain kemasan yang menunjukkan keunggulan dari sebuah merek atau produk sehingga tampilan desain mampu menjual dan tampilan kemasan dapat menarik hati konsumen. Ada beberapa hal yang harus dipenuhi dalam melakukan perancangan desain kemasan diantaranya adalah sebagai berikut: 
1. Kemasan harus menonjol;

2. Contents atau isi dari kemasan harus dapat memberikan informasi tentang isi kemasan dan apa yang terkandung dalam produk;

3. Harga atau biaya proses pembuatan kemasan harus efektif dan efisien.

\section{Label}

Label merupakan identitas atau ciri dari suatu produk. Dengan adanya label maka diharapkan konsumen dapat mampu membedakan antara produk satu dengan produk lainnya. Lebelingmerupakan salah satu upaya yang memberikan label berupa informasi-informasi singkat mengenai produk tersebut. Adapun informasi-informasi yang perlu dicantuman dalam label seperti nama produk, pembuat produk, alamat pembuat produk, bahan yang digunakan untuk membuat produk, kompoisi gizi dari produk, masa kadaluarsa, izin depkes atau instansi terkait. Pembuatan label untuk produk sangat direkomendasikan dalam upaya meningkatkan penjualan produk. Selain meningkatkan minat konsumen untuk melakukan pembelian produk, label juga berfungsi untuk menghindari terjadinya kesalahan dalam pembelian.

\section{Teknologi yang Digunakan untuk Mendesain Label}

Muhammad Suyanto (2004) mendefinisikan bahwa desain grafis merupakan aplikasi dari keterampilan seni dan komunikasi yang dibutuhkan untuk kepentingan bisnis dan industri. Aplikasi-aplikasi ini dapat mencakup periklanan dan penjualan produk, mnciptakan identitas visual yang digunakan untuk institusi, produk, dan perusahaan, lingkungan grafis, desain informasi dari produknya, dan secara visual dapat menyempurnakan pesan dalam publikasi. Desain grafis merupakan ilmu yang mempelajari mengenai bahasa visual yang salah satu kegunaannya adalah untuk keperluan penyampaian informasi dan komunikasi dari pelontar pesan.

Pesan visual yang dapat disampaikan misalnya berupa informasi produk atau jasa yang dikomunikasikan secara komunikatif dan persuasif dengan tujuan untuk publikasi, promosi, dan pemasaran yang menggunakan media informasi seperti televisi, website, majalah, surat kabar, atau brosur dan lain sebagainya sehingga pesan yang ingin disampaikan kepada sasaran dapat secara efektif dipahami, diterima, dan dapat mengubah sikap sasaransesuai dengan tujuan pemasaran. Oleh karena itu, perlu diperhatikan hal-hal sebagai berikut :

1. Komunikatif seperti visualisasinya harus mudah diterima oleh sasaran, nyaman dilihat atau dibaca, sederhana, dan menarik serta harus menampilkan apa yang disukai dan tidak menampilkan yang tidak disukai oleh sasaran;

2. Kreatif;

3. Sederhana 
4. Menggunakan bahasa visual yang harmonis, utuh, dan senada agar materi pesan dipersepsi secara utuh (komprehensif) yang menyatu dan harmonis di dalam sebuah karya grafis;

5. Penggambaran objek dalam bentuk image yang presentatif;

6. Memilih warna yang sesuai;

7. Menggunakan tipografi secara kreatif sesuai dengan keperluan dan tidak berlebihan.

8. Tata letak (layout).

Alat yang digunakan dalam desain grafis adalah sebagai berikut :

1. Adobe Photoshop ;

2. CorelDraw.

\section{SIMPULAN}

Tape merupakan salah satu makanan selingan yang cukup populer di Indonesia dan di Malaysia. Tape memiliki rasa manis dan mengandung alkohol, serta bertekstur lunak dan berair. Sebagai produk makanan, tape cepat rusak karena adanya fermentasi lanjutan setelah kondisi fermentasi tercapai secara optimum sehingga tape harus segera dikonsumsi. Agar tape tetap memiliki kualitas yang baik maka diperlukan kemasan yang mampu melindungi kualitasnya. Selain itu, kemasan yang digunakan oleh produk tape harus mampu menarik juga calon konsumen untuk membeli produk tape. Maka dari itu pentingnya peningkatan kualitas kemasan pada tape yang dapat juga meningkatkan penjualan produk tape tersebut.Kegiatan pengabdian pada masyarakat ini ditujukan untuk memberikan pengetahuan dan keterampilan pembuatan kemasan produk tape bagi produsen tape di Desa Cibeureum. Kecamatan Cibeureum, Kabupaten Kuningan. Adapun metode yang digunakan dalam kegiatan ini adalah presentasi, demonstrasi, dan praktik secara individu maupun kelompok.

\section{SARAN}

Berdasarkan kesimpulan di atas maka saran yang dapat diberikan adalah produsen tape di Desa Cibeureum. Kecamatan Cibeureum, Kabupaten Kuningan hendaknya melakukan continuous improvement dengan memperhatikan dan mengembangkan desain kemasan yang menarik sehingga diharapkan dapat membentuk citra merek yang baik dari produk tape tersebut. Selain itu, produsen tape di Desa Cibeureum. Kecamatan Cibeureum, Kabupaten Kuningan dapat memperhatikan kualitas kemasan yang digunakan dengan cara memilih bahan yang aman dan juga dapat membuat tape bertahan lama.

\section{UCAPAN TERIMA KASIH}

Penulis ucapkan terima kasih kepada Rektor Universitas Kuningan, Pemerintah Desa Cibeureum atas segala dukungan yang telah diberikan sehingga terselenggaranya kegiatan pengabdian ini. Kegiatan pengabdian ini dibiayai Dana PkM Internal 
Universitas Kuningan Berdasarkan Surat Persetujuan Rektor No. 093.40/LPPMPM/UNIKU/KNG/2019 Tanggal 19 Juni 2019

\section{DAFTAR PUSTAKA}

Dadang Suhendar dan Dadang Suhardi. 2018. Optimalisasi Pengelolaan Usaha Kecil Menengah (UKM) Kerupuk Dorokdok Desa Cibingbin Kecamatan Cibingbin, Kabupaten Kuningan. Empowerment : Jurnal Pengabdian Masyarakat, e-ISSN 2598-2052 Vol. 01 Nomor 01. 2018.45-52.

Julianti, E. dan Nurminah, M. 2006. Teknologi Pengemasan. Departemen Teknologi Pertanian, Fakultas pertanian, Universitas sumatera utara. http://ecourse.usu.ac.id/content/teknologi/teknologi/textbook.pdf

Kotler dan Armstrong. 2012. Prinsip-Prinsip Pemasaran. Edisi 13 Jilid 1. Erlangga : Jakarta

Simamora, Bilson. 2007. Panduan Riset dan Perilaku Konsumen. Jakarta: Gramedia

Kuningan.

.2018. Pemberdayaan UMKM dalam Koperasi. Edukati Press. 